\title{
Sistem Kontrol Hibrida Sinyal Rujukan Berbasis Logika Fuzzy untuk Peningkatan Kinerja Transien Pengontrol PID
}

\author{
Endra Joelianto $^{1}$ \& Oberli Tansri $^{1}$ \\ ${ }^{1}$ KK Instrumentasi dan Kontrol, \\ Fakultas Teknologi Industri, Institut Teknologi Bandung \\ Gedung LabTek VI, Lt. 3, Jl. Ganesa 10, Bandung 40132 \\ Telpon: +62-22- 2504424, Email: ejoel@tf.itb.ac.id
}

\begin{abstract}
Makalah ini membahas suatu metoda kontrol yang disebut kontrol sinyal rujukan (set-point) dengan pengambilan keputusan menggunakan logika fuzzy. Metoda ini dirancang untuk mengurangi keterbatasan sistem kontrol umpan balik yang harus mempunyai penguatan pengontrol tinggi untuk menghasilkan kinerja transien yang cepat. Metoda kontrol sinyal rujukan dapat memperbaiki kinerja transien dengan tanpa mempengaruhi karakteristik dinamik sistem kontrol lup tertutupnya. Pada makalah ini, pengontrol umpan balik yang digunakan adalah pengontrol PID dan kontrol sinyal rujukan menggunakan pengambilan keputusan dengan sistem fuzzy berdasarkan sinyal kesalahan. Kinerja metoda kontrol sinyal rujukan dengan sistem logika fuzzy dan sistem kontrol umpan balik dengan pengontrol PID diperlihatkan oleh beberapa hasil simulasi pada model umum sistem berorde satu dan dua dengan waktu mati.
\end{abstract}

Keywords: Logika Fuzzy; Pengontrol PID; Respon Transien; Sistem Kontrol Hibrida.

Abstract. The paper proposes a control method called fuzzy logic based reference (set-point) control. The proposed control method is designed to reduce inherent limitation in the conventional feedback control systems resulted from high gain feedback selection in order to achieve fast transient response. The reference control method improves the transient response performance without affecting dynamic behaviour of the conventional closed loop system. In this paper, the PID controller is selected as the feedback control system and the reference control is implemented by using fuzzy logic decision based on the error signal of the feedback control. Performances of the proposed fuzzy logic based reference control combined with the PID controller method are shown by several simulation results on first and second order systems.

Keywords: Fuzzy Logic; Hybrid Control Systems; PID Controller; Transient Response.

Makalah diterima redaksi tanggal 16 September 2006, revisi diterima tanggal 24 April 2007, diterima untuk diterbitkan tanggal 1 Mei 2007. 


\section{$1 \quad$ Latar Belakang}

Pengontrol PID (Proporsional-Integral-Derivatif) merupakan salah satu pengontrol yang dikenal luas dan telah terbukti di industri selama lebih dari tujuh dekade. Pengontrol PID ditemukan pada tahun 1922 dan sampai sekarang masih merupakan pengontrol yang paling banyak digunakan, lebih dari $80 \%$ lup kontrol umpan balik di industri saat ini masih didominasi oleh pengontrol PID [1]. Pada setiap perangkat kontrol di industri, seperti: Distributed Control Systems (DCS) maupun Programmable Logic Controller (PLC) selalu tersedia pengontrol PID dengan tambahan fitur ototala (auto-tuning) untuk memudahkan operator menjalankan sistem kontrol umpan balik dengan PID. Daya tarik utama dari pengontrol PID adalah pengontrol ini dapat dioperasikan oleh operator yang tidak mempunyai pengetahuan tentang teori atau teknik kontrol otomatik. Operator cukup berbekal pengalaman terhadap karakteristik proses yang dikontrol, berdasarkan pengetahuan ini, operator dapat menentukan parameter-parameter pengontrol PID secara coba-coba dengan hasil yang memuaskan.

Meskipun demikian, telah diketahui bahwa suatu pengontrol satu derajat kebebasan (one-degree of freedom controller) seperti pengontrol PID yang biasa terdapat pada DCS dan PLC tidak dapat ditala secara optimal untuk menghasilkan kinerja yang bagus secara serentak untuk masalah perubahan sinyal rujukan (set-point) dan masalah gangguan beban [2, 3]. Keputusan harus dilakukan dengan membuat salah satu kinerja transien dipilih optimal dan mengorbankan yang lain. Hal ini mengakibatkan proses penalaan menjadi rumit dan mahal, karena untuk setiap kinerja (perubahan sinyal rujukan atau perubahan beban) harus dilakukan penalaan secara terpisah.

Akhir-akhir ini telah diusulkan suatu metoda kontrol yang dapat digunakan untuk memperbaiki secara khusus kinerja respon transien untuk perubahan sinyal rujukan dengan tanpa mengubah karakteristik dinamik sistem lup tertutup tanpa dibatasi jenis pengontrol yang digunakan [2, 4-6]. Metoda kontrol ini berbeda dengan sistem kontrol umpan balik pada umumnya yang bertujuan untuk mencari penguatan umpan balik. Tetapi, pada metoda ini, variabel yang dikontrol adalah sinyal rujukan (set-point) sistem kontrol umpan balik lup tertutup dengan tanpa mengubah dinamika sistem umpan balik lup tertutup ataupun penguatan umpan baliknya. Sebagai akibatnya, metoda ini dapat digunakan untuk mengatasi kesukaran dalam melakukan penalaan pengontrol PID untuk mendapatkan kinerja yang bagus secara serentak pada transien respons dan peredaman gangguan, karena pengontrol PID dapat ditala untuk memberikan hasil kinerja terhadap perubahan beban yang optimal. Sedangkan kinerja transien terhadap perubahan sinyal rujukan dapat di atasi dengan metoda kontrol sinyal rujukan. 
Selain itu, telah dikenal juga sistem kontrol logika fuzzy yang berbasiskan suatu pengetahuan fenomena-fenomena pada proses untuk menentukan suatu aksi kontrol yang sesuai dengan suatu hubungan jika-maka (if-then) [7-9]. Logika fuzzy meniru aksi operator dalam merespon perubahan yang terjadi pada variabel proses. Sistem kontrol logika fuzzy telah dengan sukses diaplikasikan di berbagai sistem kontrol di industri. Pada umumnya, aplikasi logika fuzzy pada pengontrol PID ditujukan untuk menentukan parameter-parameter pengontrol PID secara on-line, dikenal sebagai metoda fuzzy swatala PID [10-11].

Pada makalah ini akan dibahas penggabungan sistem kontrol sinyal rujukan berbasis logika fuzzy dengan pengontrol PID sebagai pengontrol umpan balik. Sistem kontrol ini menggunakan logika fuzzy untuk menentukan dan memilih sinyal rujukan semu yang sesuai selama selang waktu transien. Pengontrolan sinyal rujukan semu ini dirancang akan memperbaiki kinerja transien terhadap perubahan sinyal rujukan asal (default) pada sistem kontrol lup tertutup yang dikontrol oleh pengontrol PID. Sehingga pengontrol PID dengan kontrol sinyal rujukan akan menghasilkan pengontrol PID yang mempunyai kinerja respon transien dan peredaman gangguan lebih baik dari pengontrol PID saja. Kegunaan penambahan sistem kontrol rujukan pada pengontrol PID akan ditunjukkan dengan melakukan simulasi pada komputer.

\section{Formulasi Masalah}

Perbaikan kinerja respon transien pengontrol PID dilakukan dengan menambahkan suatu sistem kontrol untuk mengubah perubahan sinyal rujukan semu yang pada suatu saat harus kembali kepada sinyal rujukan asalnya. Obyektif dari pengontrolan hibrida sinyal rujukan adalah untuk memperbaiki kinerja transien sistem kontrol umpan balik PID terhadap sinyal rujukan asal. Sistem kontrol sinyal rujukan ini menggunakan informasi sinyal kesalahan $e(t) \equiv(r(t)-y(t))$ untuk selanjutnya akan diolah dengan menggunakan logika fuzzy untuk menentukan sinyal rujukan semu yang sesuai sehingga respon transien terhadap perubahan sinyal rujukan menjadi memenuhi spesifikasi dengan lebih baik. Setelah kesalahan antara keluaran proses dengan sinyal rujukan asal memenuhi batas toleransi yang ditetapkan (misal $|e(t)| \leq \varepsilon$, dengan $\varepsilon$ cukup kecil), maka sistem kontrol sinyal rujukan berbasis fuzzy berhenti mengubah sinyal rujukan semu dan mengembalikannya ke sinyal rujukan asal.

Diagram blok sistem kontrol hibrida sinyal rujukan berbasis logika fuzzy dengan pengontrol PID diperlihatkan oleh Gambar 1 di bawah ini. Sistem kontrol hibrida ini terdiri dari sistem kontrol lup tertutup dengan pengontrol PID yang bekerja secara kontinyu dan suatu mekanisme pengubah sinyal rujukan yang 
dilakukan oleh aturan fuzzy untuk memberikan sinyal rujukan semu pada kejadian diskrit (discrete event) [2]. Pengontrolan sinyal rujukan semu berlangsung selama kesalahan $e(t)$ dipandang besar oleh mekanisme di aturan fuzzy dan mengembalikannya ke sinyal rujukan asal jika kesalahan sudah kecil. Mekanisme seperti ini dikenal sebagai sistem hibrida karena sinyal rujukan bekerja secara diskrit, yaitu pada selang waktu tertentu sinyal rujukan semu diubah jika kesalahan masih besar dan kemudian kembali ke sinyal rujukan asal jika kesalahan sudah kecil pada setiap waktu cacah yang telah ditentukan. Kejadian diskrit terjadi pada setiap pengubahan sinyal rujukan selama kesalahan dapat terjadi pada selang waktu tertentu, demikian juga ketika sinyal rujukan asal dapat terjadi pada selang waktu yang lama ketika kesalahan tidak keluar dari toleransi kesalahan yang diperbolehkan.

Gambar 1 memperlihatkan perancangan sistem fuzzy sinyal rujukan (fuzzy setpoint system) dengan satu masukan kesalahan $e(t)$ ). Aturan fuzzy akan bekerja mengubah sinyal rujukan asal (original/default set-point) ketika kesalahan $e(t)$ cukup besar sehingga keluaran plant $y(t)$ akan kembali ke sinyal rujukan asal atau yang baru dengan kinerja transien yang optimal, misal lonjakan maksimum lebih kecil, waktu naik lebih cepat, waktu tunak lebih cepat, dst.

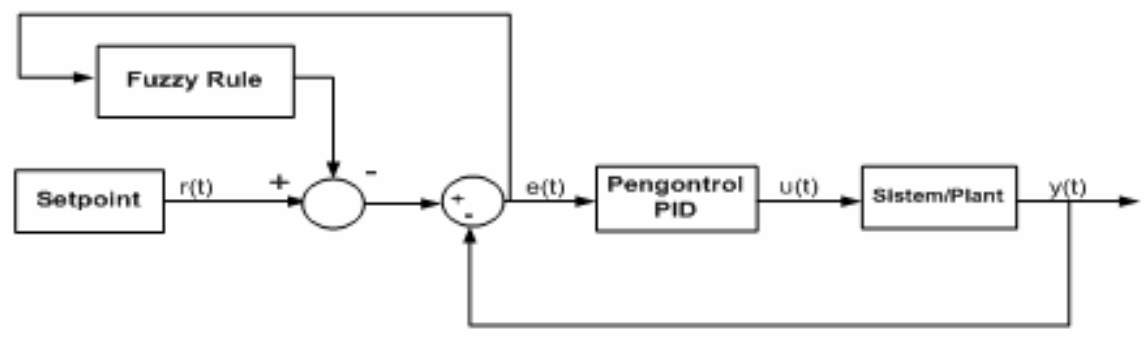

Gambar 1 Diagram blok sistem kontrol hibrida sinyal rujukan berbasis logika fuzzy dengan pengontrol PID sebagai umpan balik.

\subsection{Pengontrol PID}

Kombinasi aksi kontrol proporsional, integral, dan derivatif dikenal sebagai aksi kontrol proporsional-integral-derivatif (PID). Persamaan pengontrol PID bentuk standar [3, 12-14] direpresentasikan oleh persamaan berikut:

$$
u(t)=K_{p} e(t)+\frac{K_{p}}{T_{i}} \int_{0}^{t} e(t) d t+K_{p} T_{d} \frac{d e(t)}{d t}
$$


dengan $e(t) \stackrel{\Delta}{=} r(t)-y(t)$, dalam fungsi alih persamaan pengontrol PID (1) dapat dituliskan sebagai berikut:

$$
G_{c}(s)=K_{p}\left(1+1 /\left(T_{i} s\right)+T_{d} s\right)
$$

dengan $K_{p}$ adalah penguatan proporsional, $T_{i}$ adalah waktu integral, $T_{d}$ adalah waktu derivatif.

Penentuan parameter-parameter PID, yaitu: $K_{p}, T_{i}$ dan $T_{d}$ dapat dilakukan dengan mengunakan metoda-metoda penalaan yang telah dikenal luas, seperti: Ziegler-Nicholls, Cohen-Coon, dan lain-lainnya [3, 12-14]. Tetapi penalaan dapat juga dilakukan dengan cara coba-coba (trial and error) berdasarkan keperluan untuk mendapatkan suatu kinerja respon transien yang memenuhi kriteria dan kestabilan sistem lup tertutupnya [3, 12-14]. Misal, diberikan kriteria respons transien berupa syarat lonjakan maksimum (maximum overshoot) adalah sebesar 20\%, penentuan parameter pengontrol PID secara coba-coba menghasilkan nilai-nilai parameter $K_{p}, T_{i}$ dan $T_{d}$ pada beberapa tipikal sistem, yaitu sistem orde satu dan dua dengan waktu mati yang secara umum dapat dianggap mewakili perilaku dinamika di industri proses [12-13].

1. Sistem orde satu

Persamaan matematik sistem orde satu dengan waktu mati (dead time) dapat ditulis dalam fungsi alih sebagai berikut:

$$
\frac{Y(s)}{U(s)}=\frac{k_{g} e^{-L s}}{T_{a} s+1}
$$

dengan $k_{g}=$ penguatan sistem/plant, $L=$ waktu tunda $\operatorname{dan} T_{a}=$ konstanta waktu.

Misalkan sistem berorde satu mempunyai waktu tunda 30 detik, penguatan sistem 30 dan konstanta waktu 40 detik, fungsi alih sistem dapat dituliskan sebagai persamaan (3) sebagai berikut.

$$
G(s)=\frac{5 e^{-30 s}}{40 s+1}
$$


Parameter PID pada sistem orde satu ditala dengan metoda coba-coba didapatkan beberapa harga harga $K_{p}, T_{i}$ dan $T_{d}$, respon keluaran yang sesuai dengan kriteria yang diinginkan. Dari hasil penalaan coba-coba, beberapa harga parameter PID dipilih harga parameter-parameter yang memiliki waktu naik $\left(T_{r}\right.$ ) yang paling cepat dan harga lonjakan maksimum sudah memenuhi dibawah 20\% yaitu: $K_{p}=0,2, T_{i}=45$ detik dan $T_{d}=15$ detik. Hasil respon dengan harga parameter PID ini dapat dilihat pada Gambar 2.

2. Sistem orde dua

Sistem orde dua dengan waktu tunda yang digunakan dalam simulasi merupakan modifikasi dari sistem orde satu di atas dengan fungsi alih berikut:

$$
G(s)=\frac{5 e^{-30 s}}{s^{2}+9 s+20}
$$

Parameter PID untuk sistem orde dua juga didapatkan dengan menggunakan cara yang sama seperti pada sistem orde satu. Dari hasil penalaan, diperoleh harga parameter PID yang terbaik yaitu $K_{p}=0,05, T_{i}=0,6$ detik dan $T_{d}=15$ detik. Respon keluaran dengan menggunakan parameter pengontrol PID hasil penalaan ini diperlihatkan pada Gambar 3.

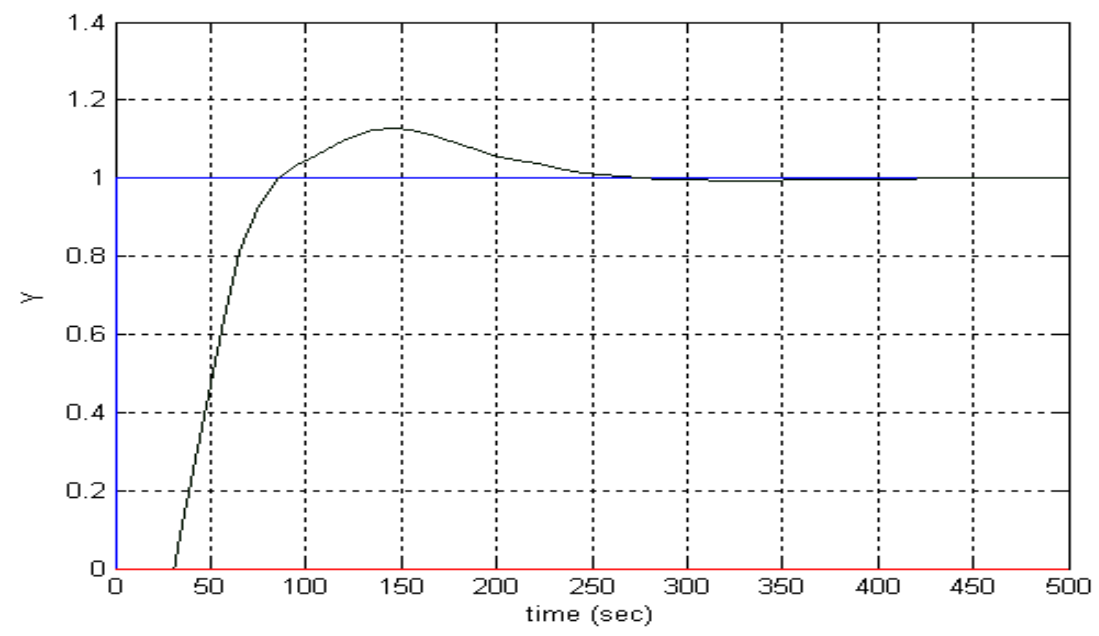

Gambar 2 Respon keluaran dengan $K_{p}=0,2, T_{i}=45$ detik, $T_{d}=15$ detik. 


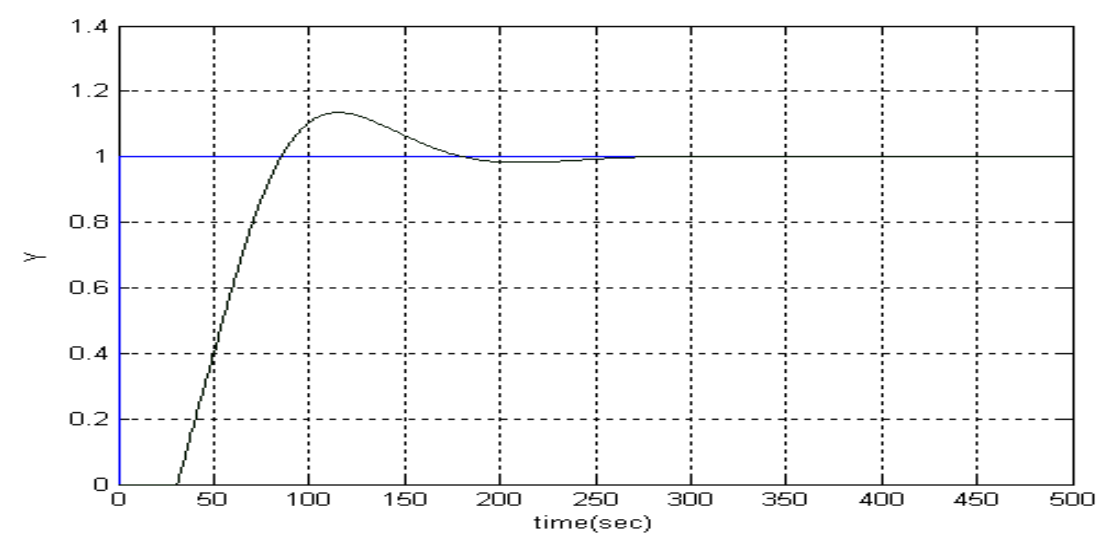

Gambar 3 Respon keluaran dengan $K_{p}=0,05, T_{d}=0,6$ detik, $T_{i}=15$ detik.

\section{$3 \quad$ Perancangan Sistem Fuzzy Sinyal Rujukan}

Pada perancangan sistem keputusan berdasarkan logika fuzzy untuk menentukan besarnya sinyal rujukan semu yang akan diberikan kepada sistem kontrol lup tertutup, sebelumnya perlu ditentukan jumlah variabel masukan dan keluaran sistem logika fuzzy. Sistem fuzzy ini yang selanjutnya disebut sistem fuzzy sinyal rujukan (fuzzy set-point system) yang dibuat pada makalah ini terdiri dari satu variabel masukan untuk fuzzy rujukan satu masukan, yang masing masing berasal dari sinyal kesalahan pada sistem orde satu dan orde dua. Agar keputusan dari sistem fuzzy sinyal rujukan dapat menjalankan tahap-tahap dalam proses sistem inferensi fuzzy (Fuzzy Inference System) dan menghasilkan sinyal keluaran semu yang dapat mengontrol respon transien sistem lup tertutup yang dikontrol oleh pengontrol PID sesuai dengan yang diinginkan, perlu dilakukan langkah-langkah sebagai berikut:

1. Menentukan variabel masukan sistem fuzzy sinyal rujukan beserta fungsi keanggotaannya.

2. Menentukan variabel keluaran sistem fuzzy sinyal rujukan beserta fungsi keanggotaannya.

3. Menentukan aturan 'jika - maka' fuzzy yang menentukan hubungan masukan dan keluaran sistem keputusan.

\subsection{Variabel Masukan Sistem Fuzzy Sinyal Rujukan}

Perancangan logika fuzzy pada sistem fuzzy sinyal rujukan satu masukan pada sistem berorde satu dan berorde dua dengan waktu mati dibahas pada bagian berikut. 
1. Sistem orde satu

Grafik Fungsi keanggotaan sistem fuzzy sinyal rujukan dengan satu variabel masukan diperlihatkan pada Gambar 4 dibawah ini. Variabel masukan pada sistem fuzzy sinyal rujukan adalah sinyal kesalahan $e(t)$ dengan nilai variabel masukan dibatasi -1 sampai 1 sebagai semesta pembicaraannya. Berdasarkan beberapa percobaan yang dilakukan, disusun fungsi keanggotaan fuzzy dan digambarkan oleh tujuh fungsi keanggotaan segitiga yang masing-masing mewakili himpunan fuzzy: Negative Big (NB), Negative Medium (NM), Negative Small (NS), NONE, Positive Small (PS), Positive Medium (PM), Positive Big (PB), dan dua fungsi keanggotaan trapesium yang masing masing mewakili himpunan fuzzy: Positive Very Big (PVB) dan Negative Very Big (NVB).

2. Sistem orde dua

Variabel masukan dan fungsi keanggotaan sistem fuzzy sinyal rujukan pada sistem orde dua memakai variabel masukan fuzzy yang sama seperti pada sistem orde satu, yaitu menggunakan sinyal kesalahan $e(t)$ dan fungsi keanggotaan berbentuk segitiga dan trapesium seperti diperlihatkan oleh Gambar 4.

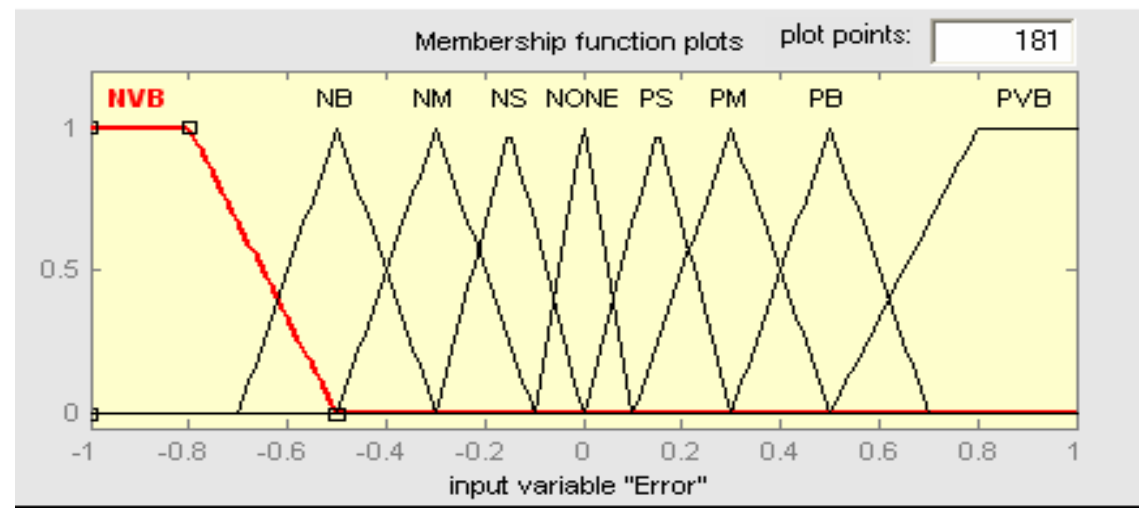

Gambar 4 Grafik variabel masukan pada sistem fuzzy sinyal rujukan dengan satu masukan pada sistem orde satu.

\subsection{Variabel Keluaran Sistem Fuzzy Sinyal Rujukan}

Keluaran logika fuzzy pada sistem fuzzy sinyal rujukan dengan satu masukan pada sistem berorde satu dan berorde dua dengan waktu mati menggunakan variabel dan fungsi keanggotaan yang berbeda dengan variabel masukan. 
1. Sistem orde satu

Pada variabel keluaran sistem fuzzy sinyal rujukan memiliki tujuh variabel, yaitu: Negative Big (NB), Negative Medium (NM), Negative Small (NS), Negative Very Small (NVS), Default (D), Positive Very Small (PVS), Positive Small (PS), Positive Medium (PM) dan Positive Big (PB) dengan menggunakan fungsi keanggotaan Gaussian, seperti Gambar 5. Variabel keluaran fuzzy dibatasi pada nilai antara -0,2 sampai 0,2 sebagai semesta pembicaraannya.

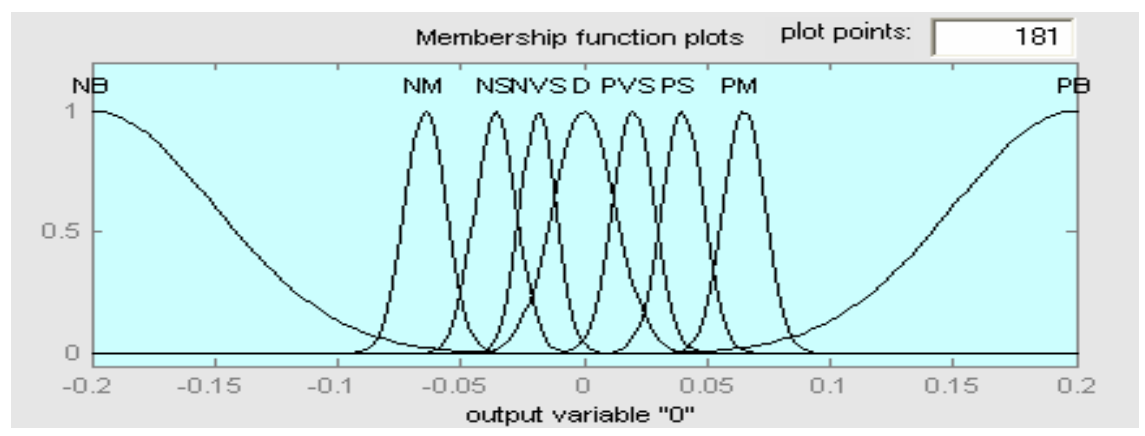

Gambar 5 Grafik variabel keluaran sistem fuzzy sinyal rujukan satu masukan pada sistem orde satu.

\section{Sistem orde dua}

Pada variabel keluaran memiliki tujuh variabel, yaitu: Negative Big (NB), Negative Medium (NM), Negative Small (NS), Negative Very Small (NVS), Default (D), Positive Very Small (PVS), Positive Small (PS), Positive Medium (PM) dan Positive Big (PB) dengan menggunakan fungsi keanggotaan Gaussian, seperti Gambar 6. Variabel keluaran fuzzy dibatasi pada nilai antara 0.4 sampai 0.4 sebagai semesta pembicaraannya.

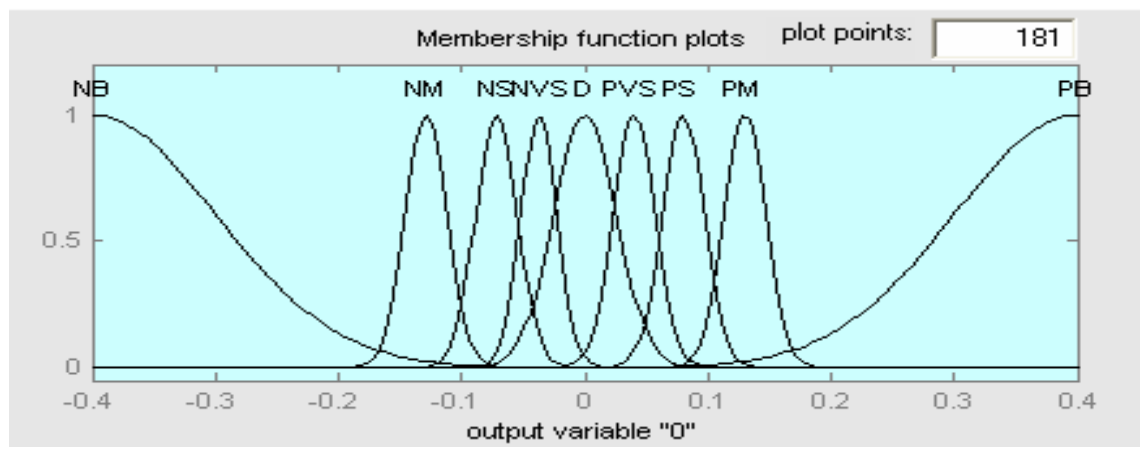

Gambar 6 Grafik variabel keluaran sistem fuzzy sinyal rujukan satu masukan pada sistem orde dua. 


\subsection{Aturan Fuzzy “Jika - Maka”}

Cara penentuan aturan fuzzy jika-maka adalah dengan menerapkan cara berpikir sesuai logika manusia dalam pernyataan jika-maka. Konsep pemikiran manusia yang digunakan adalah sebagai berikut:

1. Sinyal kesalahan didapat dari pengurangan sinyal rujukan asal dengan sinyal keluaran sistem/plant.

2. Jika sinyal kesalahan kecil maka diberi sinyal rujukan semu yang besar, jika sinyal kesalahan besar maka diberi sinyal rujukan semu yang mendekati sinyal rujukan asal dan jika kesalahan melebihi sinyal rujukan asal maka di beri sinyal rujukan asal.

3. Sistem fuzzy sinyal rujukan akan mengakibatkan sinyal kontrol yang di hasilkan oleh pengontrol PID memperbaiki waktu naik dan meminimalkan lonjakan maksimum dari respon transien keluaran sistem lup tertutup.

Pengkombinasian himpunan-himpunan fuzzy pada masukan dan keluaran sistem fuzzy sinyal rujukan maka menghasilkan 9 aturan fuzzy satu masukan jika-maka seperti yang ditunjukkan pada Gambar 7, baik untuk sistem orde satu maupun orde dua.

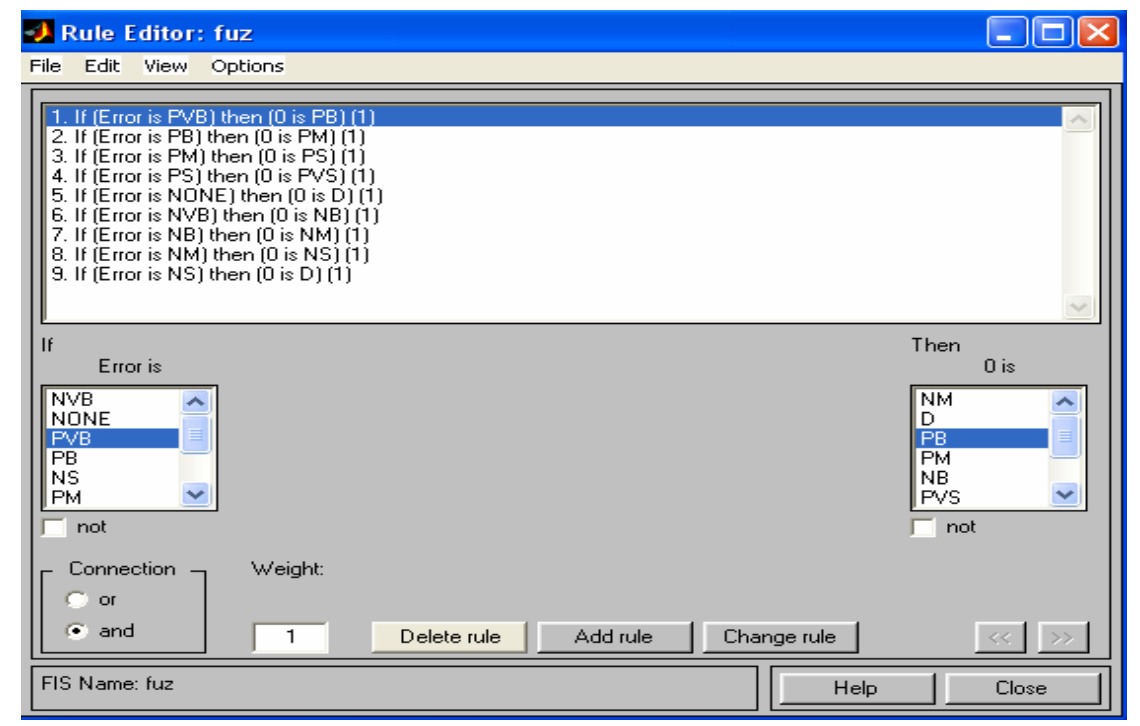

Gambar 7 Aturan fuzzy untuk satu masukan pada Rule Editor MATLAB.

Perbaikan kinerja respon transien sistem kontrol dengan pengontrol PID dilakukan dengan menggunakan sistem fuzzy sinyal rujukan yang menjalankan 5 tahap dalam proses Fuzzy Inference System (FIS) tipe Mamdani. Fuzzifikasi masukan dilakukan dengan menggunakan pemfuzzifikasi pemetaan singleton. 
Selanjutnya, aplikasi operator keluaran fuzzy menggunakan AND (MIN), OR (MAX) dan NOT. Implikasi keluaran menggunakan operator implikasi MIN Mamdani. Metoda agregrasi yang digunakan adalah agregasi keluaran MAX dan defuzzifikasi centroid. Bobot yang digunakan pada setiap aturan adalah satu. Selanjutnya dibuat beberapa pola aturan Jika-Maka dari sistem fuzzy untuk menghasilkan perbaikan waktu tunak $\left(T_{s}\right)$, lonjakan maksimum $\left(M_{p}\right)$, dan energi kontrol. Pola aturan yang sesuai diperlihatkan pada Gambar 7.

\section{$4 \quad$ Simulasi}

Dalam simulasi ini, sistem fuzzy sinyal rujukan dengan satu masukan bekerja pada kejadian diskrit sedangkan pengontrol PID menggunakan nilai parameterparameter yang telah didapatkan di atas bekerja berdasarkan waktu kontinyu. Gabungan keduanya membentuk sistem kontrol hibrida sinyal rujukan berbasis logika fuzzy yang mampu memperbaiki respon transien dibanding jika hanya menggunakan pengontrol PID saja. Simulasi dilakukan untuk sistem orde satu dan orde dua dengan waktu mati sebesar 30 detik. Diagram blok simulasi diperlihatkan oleh Gambar 8 dan Gambar 9 berikut ini.

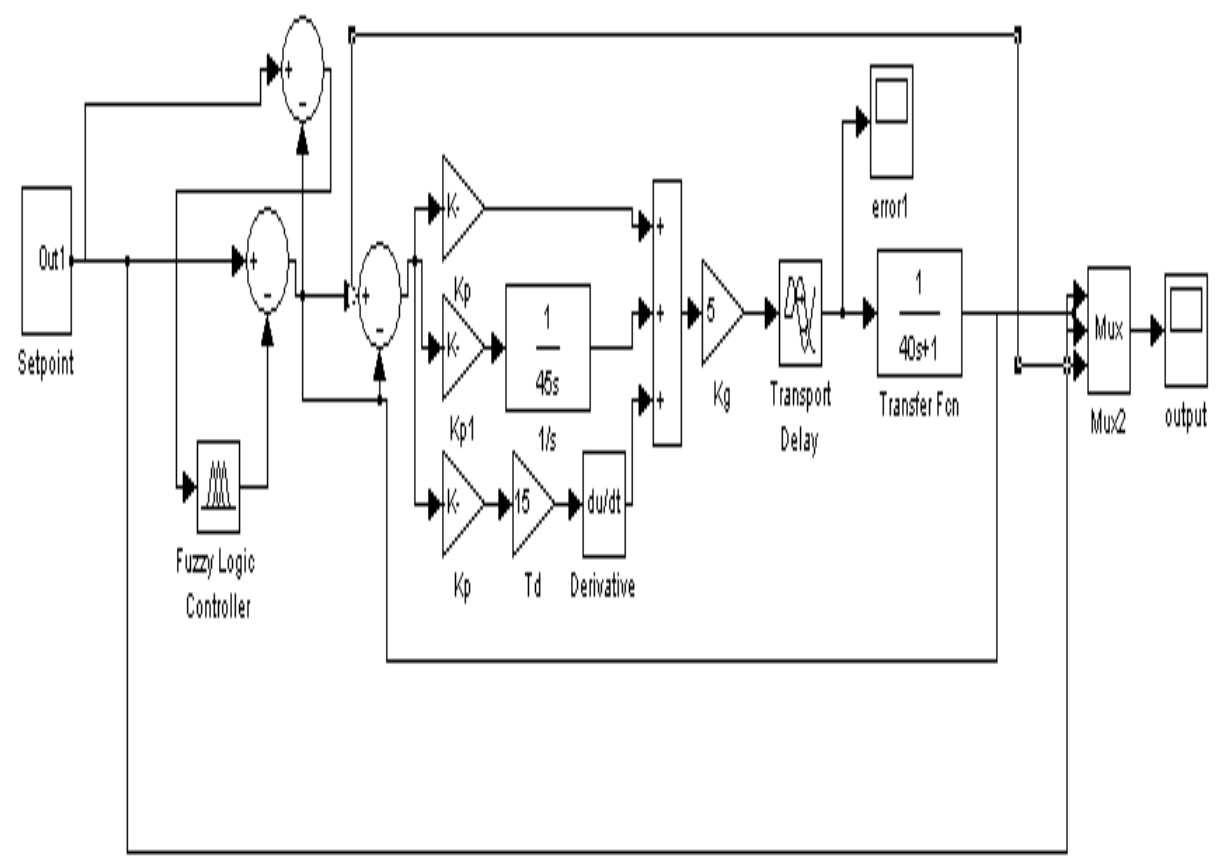

Gambar 8 Diagram blok Simulink untuk sistem orde satu. 


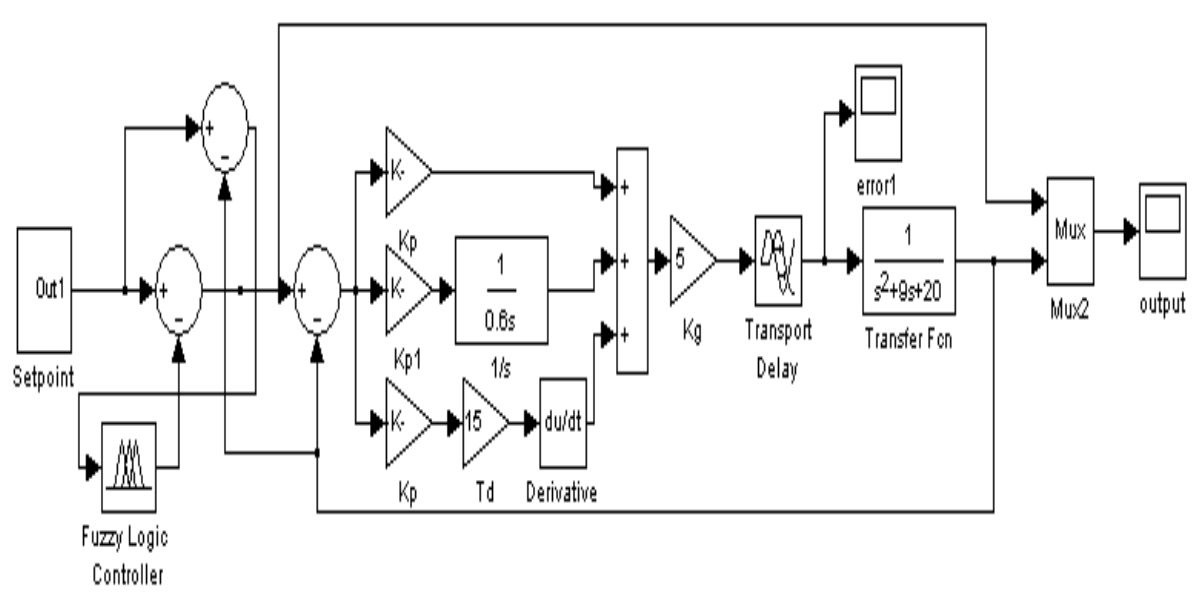

Gambar 9 Diagram blok Simulink untuk sistem orde dua.

Pada simulasi dipilih sinyal rujukan asal berupa sinyal tangga dan ditetapkan mempunyai amplituda sebesar 1 . Simulasi ini dijalankan dengan menggabungkan pengontrol PID dan pengontrol sistem fuzzy sinyal rujukan dalam Simulink Matlab versi 6.5. Fungsi keanggotaan variabel keluaran fuzzy mengalami pergeresan nilai setelah digabungkan dengan aturan fuzzy "jika maka” untuk mencapai perbaikan respon transien yang diinginkan. Perubahan nilai fungsi keanggotaan untuk setiap pengontrol sistem fuzzy sinyal rujukan satu masukan pada sistem orde satu dan orde dua dengan waktu mati diperlihatkan pada Gambar 10 dan Gambar 11 berikut ini.

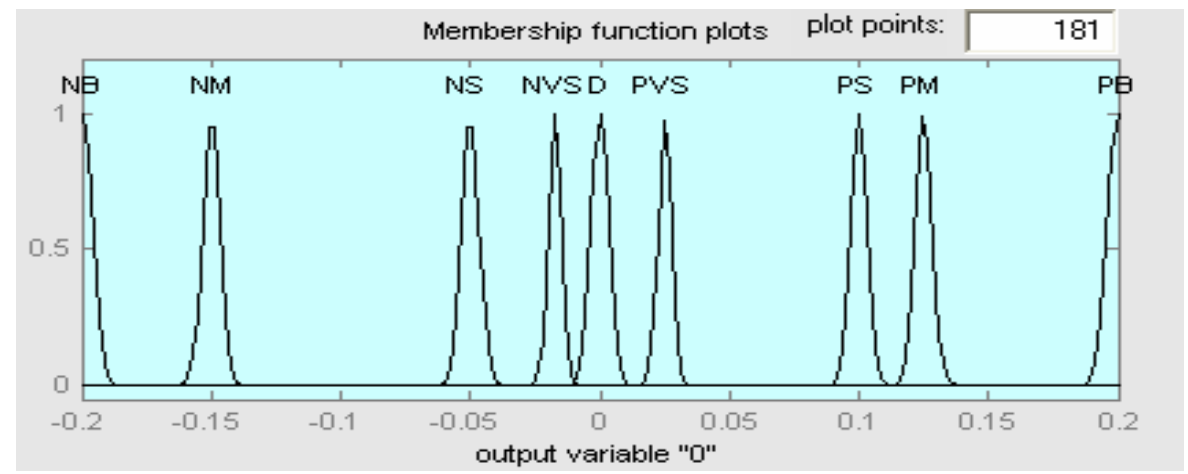

Gambar 10 Grafik akhir variabel keluaran fuzzy satu masukan pada sistem orde satu. 


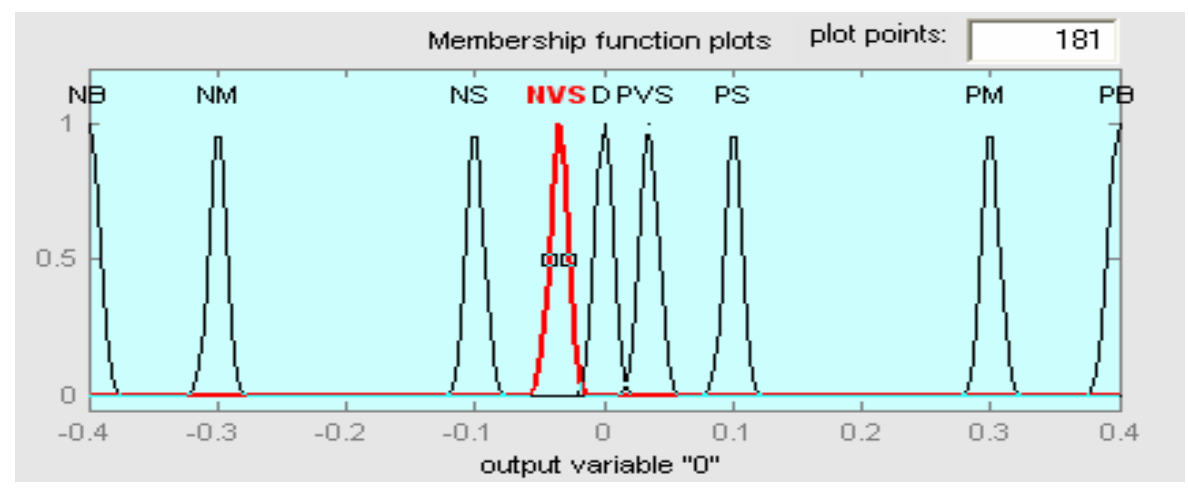

Gambar 11 Grafik akhir variabel keluaran fuzzy satu masukan pada sistem orde dua.

\subsection{Simulasi Pengontrol Sistem Fuzzy Sinyal Rujukan Satu Masukan pada Sistem Orde Satu}

Gambar 12 dan Gambar 13 memperlihatkan kinerja respon transien sistem kontrol lup tertutup dengan pengontrol PID. Gambar 14-15 memperlihatkan respon transien, bentuk sinyal rujukan semu dan sinyal kontrol yang dihasilkan dengan menggunakan pengontrol PID sebagai sistem kontrol umpan balik dengan sistem fuzzy sinyal rujukan.

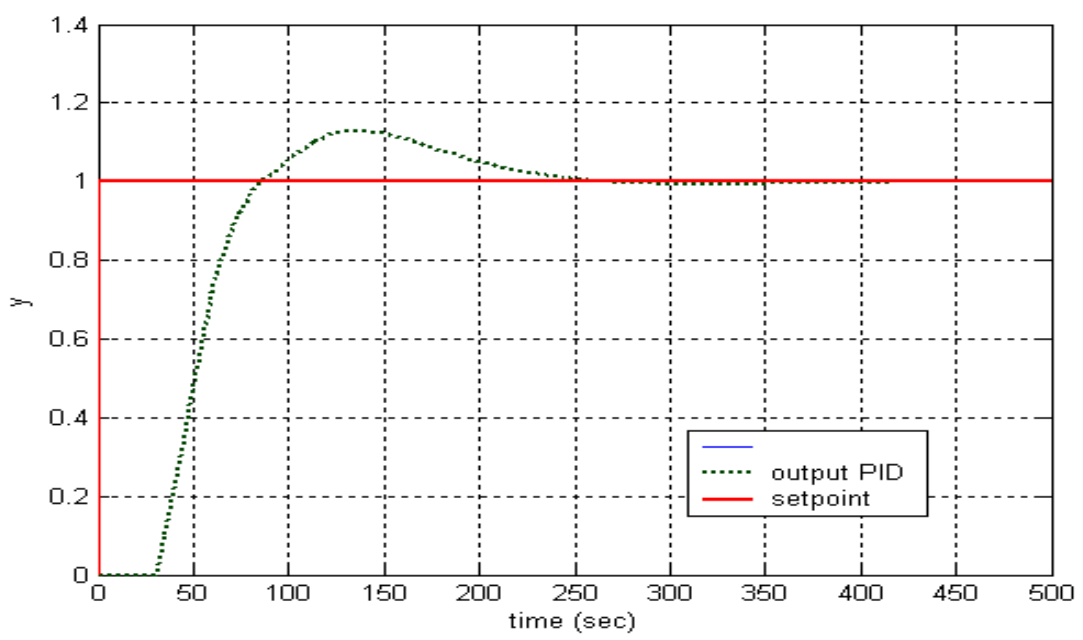

Gambar 12 Respon keluaran sistem orde satu dengan pengontrol PID. 


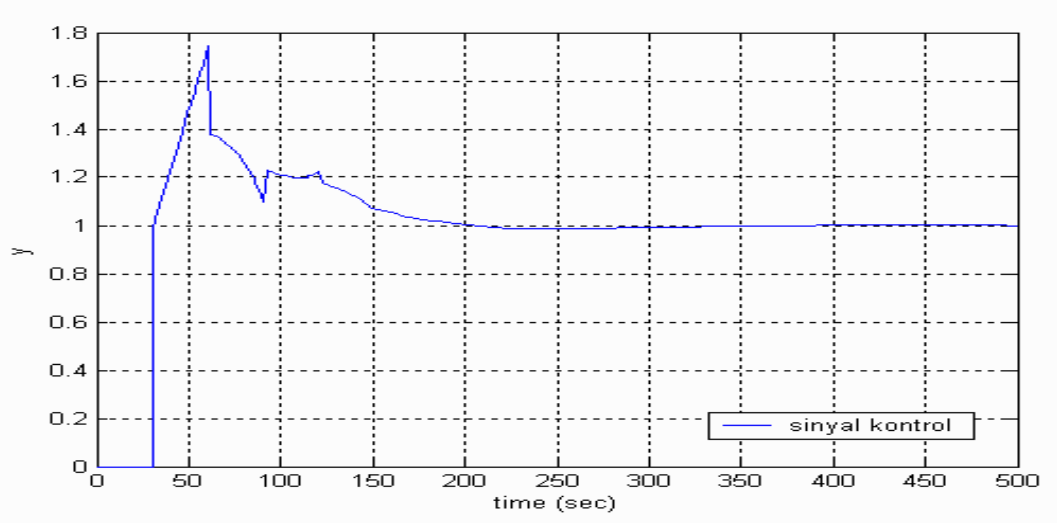

Gambar 13 Sinyal kontrol u(t) pengontrol PID pada sistem orde satu.

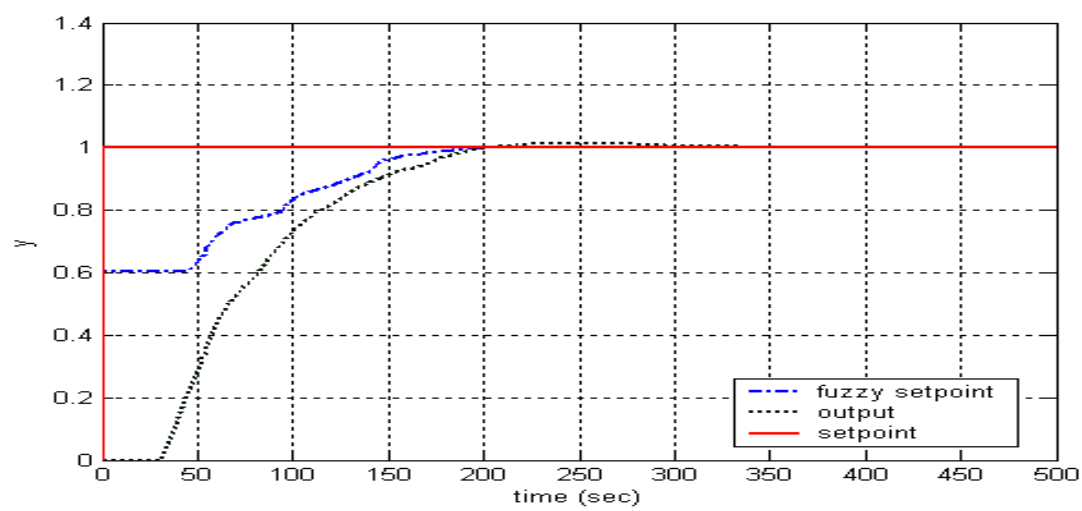

Gambar 14 Respon keluaran sistem orde satu dengan sistem fuzzy sinyal rujukan satu masukan.

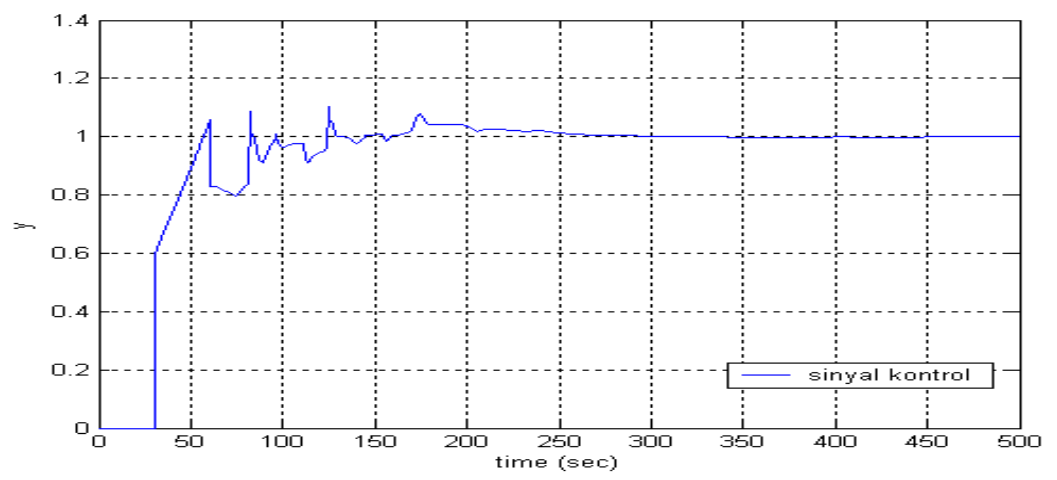

Gambar 15 Sinyal kontrol u(t) dengan sistem fuzzy sinyal rujukan satu masukan. 
Tabel 1 Data Pengamatan Kinerja Respon Transien

\begin{tabular}{cccccccc}
\hline Pengontrol & $\begin{array}{c}\text { Sinyal } \\
\text { rujukan }\end{array}$ & $\operatorname{Tr}(\mathbf{s})$ & $\mathbf{T d}(\mathbf{s})$ & $\mathbf{T p}(\mathbf{s})$ & $\mathbf{T s}(\mathbf{s})$ & $\mathbf{M p ( \% )}$ & $\int u^{2} d t$ \\
\hline PID & 1 & 87,4 & 61,2 & 152,38 & 272,38 & 11 & 1,08 \\
$\begin{array}{c}\text { Sistem kontrol } \\
\text { hibrida }\end{array}$ & 1 & 184,05 & 72,9 & 238,9 & 308,94 & 1 & 0,911 \\
\hline
\end{tabular}

Dari data pengamatan terlihat bahwa sistem kontrol hibrida sinyal rujukan berbasis logika fuzzy mampu memperbaiki respon transien dengan menurunkan harga lonjakan maksimum $M_{p}$ dari $11 \%$ menjadi $1 \%$, namum waktu naik $T_{r}$ makin membesar $51 \%$, waktu tunak $T_{s}$ semakin cepat $11 \%$ dan energi kontrol $\int u^{2} d t$ turun sebesar $15,7 \%$ dibandingkan pengontrol PID saja.

\subsection{Simulasi Fuzzy Set-Point Satu Masukan pada Sistem Orde Satu dengan Sinyal Rujukan Tangga Berubah}

Pada pengujian bagian ini sinyal rujukan dinaikkan sebesar 1 setiap 500 detik sampai 2000 detik pada sistem orde satu dengan menggunakan pengontrol PID kemudian dibandingkan dengan pengontrol hibrida sinyal rujukan berbasis logika fuzzy satu masukan.

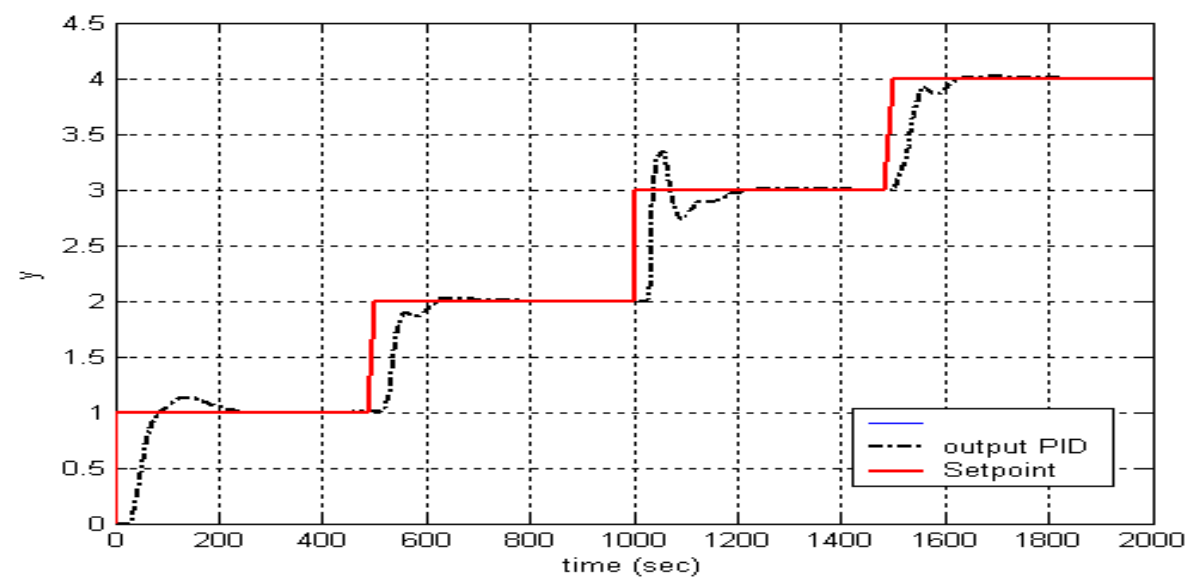

Gambar 16 Respon keluaran orde satu dengan sinyal rujukan tangga berubah dengan pengontrol PID. 


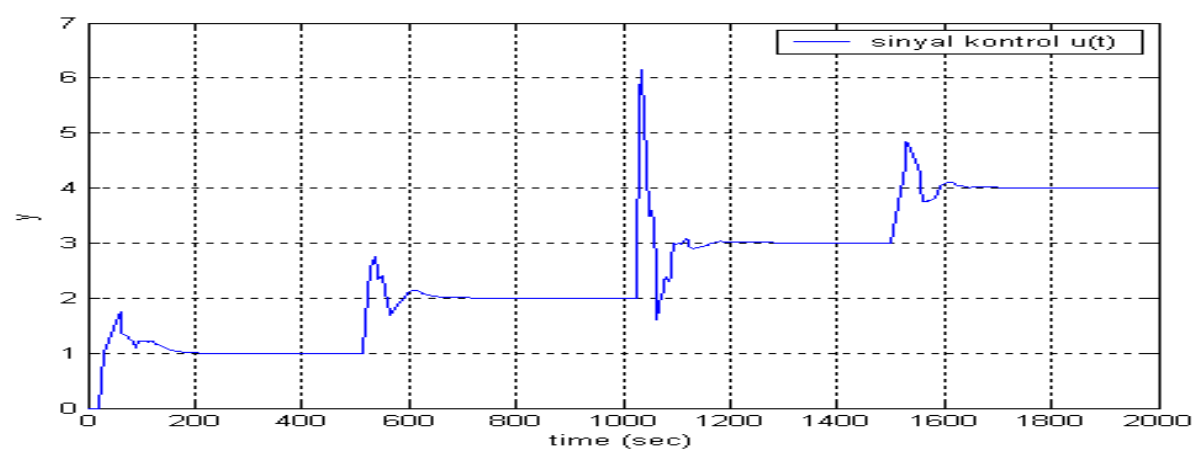

Gambar 17 Sinyal kontrol u(t) orde satusinyal rujukan tangga berubah dengan pengontrol PID.

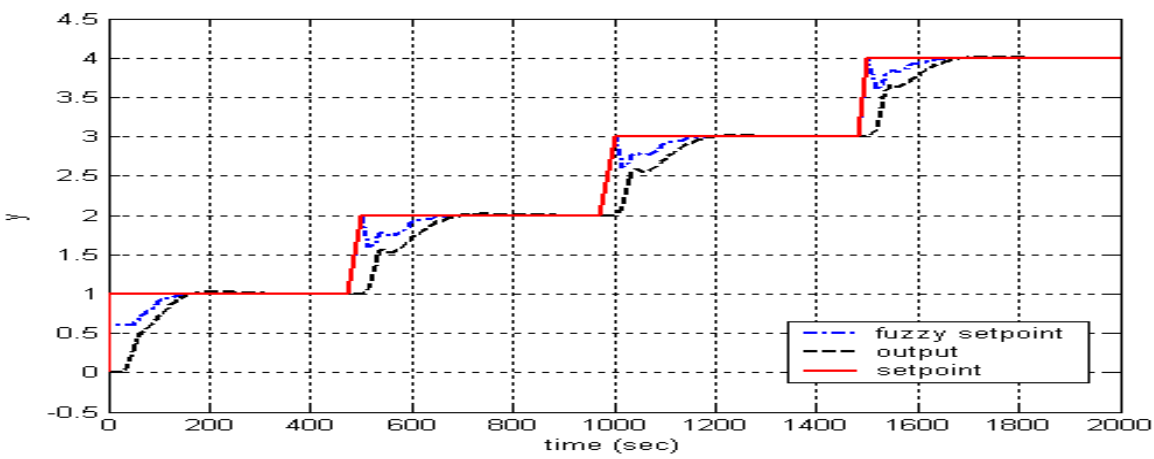

Gambar 18 Respon keluaran orde satu sinyal tangga berubah dengan pengontrol hibrida sinyal rujukan berbasis logika fuzzy satu masukan.

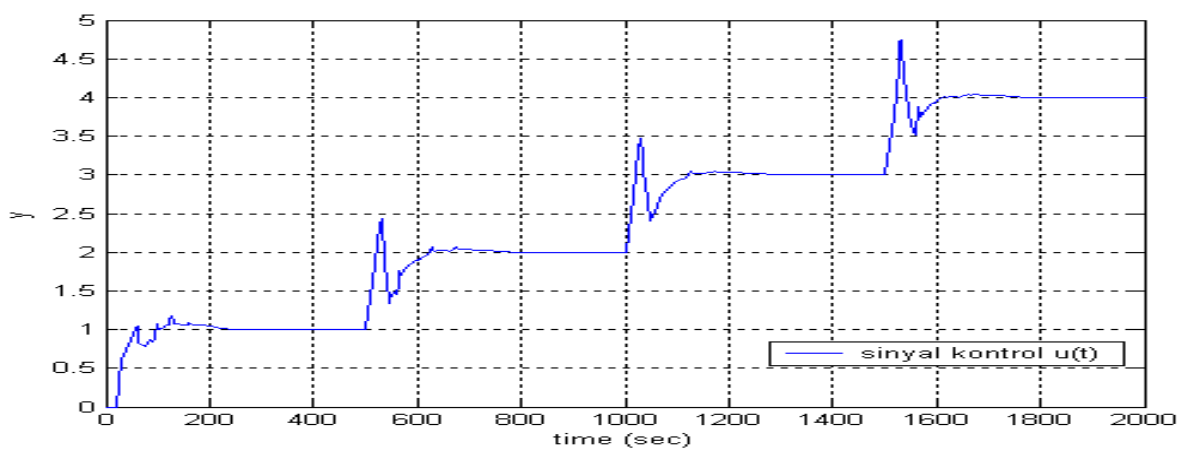

Gambar 19 Respon sinyal kontrol u(t) orde satu sinyal tangga berubah dengan pengontrol hibrida sinyal rujukan berbasis logika fuzzy satu masukan. 
Tabel 2 Data Pengamatan Kinerja Respon Transien.

\begin{tabular}{cccccccc}
\hline Pengontrol & $\begin{array}{c}\text { Sinyal } \\
\text { rujukan }\end{array}$ & $\mathbf{T r}(\mathbf{s})$ & $\mathbf{T d}(\mathbf{s})$ & $\mathbf{T p ( s )}$ & $\mathbf{T s}(\mathbf{s})$ & $\mathbf{M p ( \% )}$ & $\boldsymbol{u}^{2} d t$ \\
\hline \multirow{2}{*}{ PID } & 1 & 90,69 & 52,25 & 165,18 & 219,78 & 11 & 1,08 \\
& 2 & 639,19 & 551,22 & 679,19 & 767,55 & 2 & 0,945 \\
& 3 & 1051,8 & 1056,12 & 1101,7 & 1213,7 & 36 & 1,63 \\
Sistem & 4 & 1608,5 & 1585,3 & 1702,6 & 1809,3 & 3 & 0,958 \\
Kontrol & $\mathbf{1}$ & $\mathbf{1 4 4 , 3 1}$ & $\mathbf{7 1 , 4 2}$ & $\mathbf{2 2 3 , 2 9}$ & $\mathbf{1 8 3 , 8 8}$ & $\mathbf{0 , 9 5}$ & $\mathbf{0 , 9 1 1}$ \\
Hibrida & $\mathbf{2}$ & $\mathbf{6 8 6 , 2 4}$ & $\mathbf{5 3 8 , 5 5}$ & $\mathbf{7 5 0 , 4 5}$ & $\mathbf{6 9 1 , 3 5}$ & $\mathbf{0 , 8 6}$ & $\mathbf{0 , 8 9 8}$ \\
& $\mathbf{3}$ & $\mathbf{1 1 9 2 , 6 9}$ & $\mathbf{1 0 6 4}$ & $\mathbf{1 1 8 7 , 6}$ & $\mathbf{1 1 8 4 , 3}$ & $\mathbf{0 , 9}$ & $\mathbf{0 , 9 0 3}$ \\
& $\mathbf{4}$ & $\mathbf{1 6 5 6}$ & $\mathbf{1 5 8 9 , 2}$ & $\mathbf{1 7 3 4 , 4}$ & $\mathbf{1 6 8 2 , 6}$ & $\mathbf{0 , 9 3}$ & $\mathbf{0 , 9 0 7}$ \\
\hline
\end{tabular}

Tabel 2 memperlihatkan perbandingan respon keluaran pengontrol PID dengan Pengontrol hibrida sinyal rujukan berbasis logika fuzzy memperlihatkan pengontrol pengontrol hibrida sinyal rujukan memberikan respon keluaran yang konsisten dan baik terhadap perubahan setpoint dengan rata-rata lonjakan maksimum $M_{p}$ sebesar 0,86\%-0,95\% untuk pengontrol sedangkan pengontrol PID menghasilkan lonjakan maksimum 36\%-2\%, waktu tunak $T_{s}$ juga diperbaiki lebih cepat sekisar $1.1 \%$. Tetapi waktu naik $T_{r}$ mengalami kenaikan berkisar antara 0,07 \% - 45,2 \%. Hasil-hasil ini diperlihatkan pada Gambar 16 dan Gambar 18.

\subsection{Simulasi Sistem Orde Satu Sistem Fuzzy Sinyal Rujukan dengan Gangguan (Disturbance)}

Pada percobaan ini, sistem/plant diberi gangguan sinyal pulsa sebesar 0,04, pada rentang waktu 150 detik sampai 200 detik untuk pengontrol PID dan pengontrol hibrida sinyal rujukan satu masukan. Hasil simulasi ditunjukkan oleh Gambar 20 - 23 dan data hasil simulasi diperlihatkan pada Tabel 3.

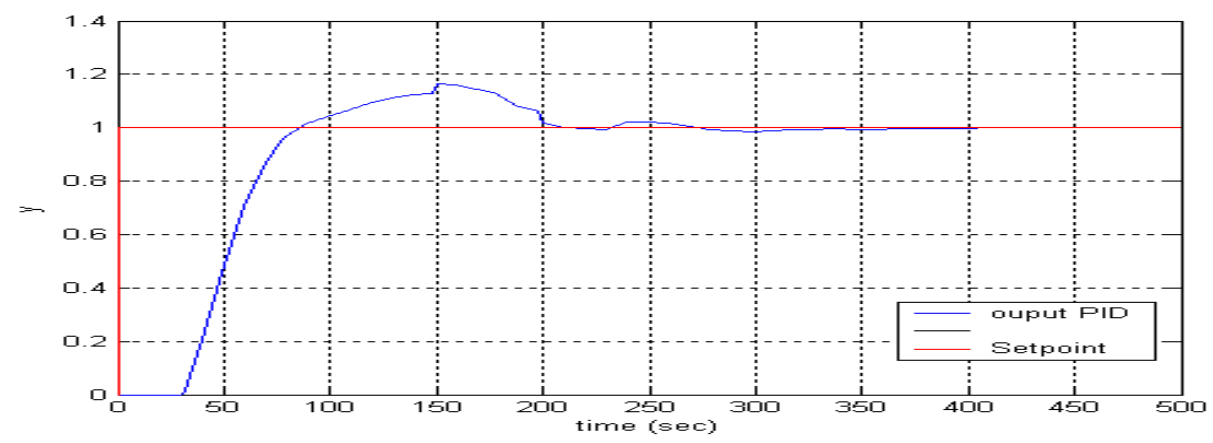

Gambar 20 Respon keluaran orde satu PID dengan gangguan. 


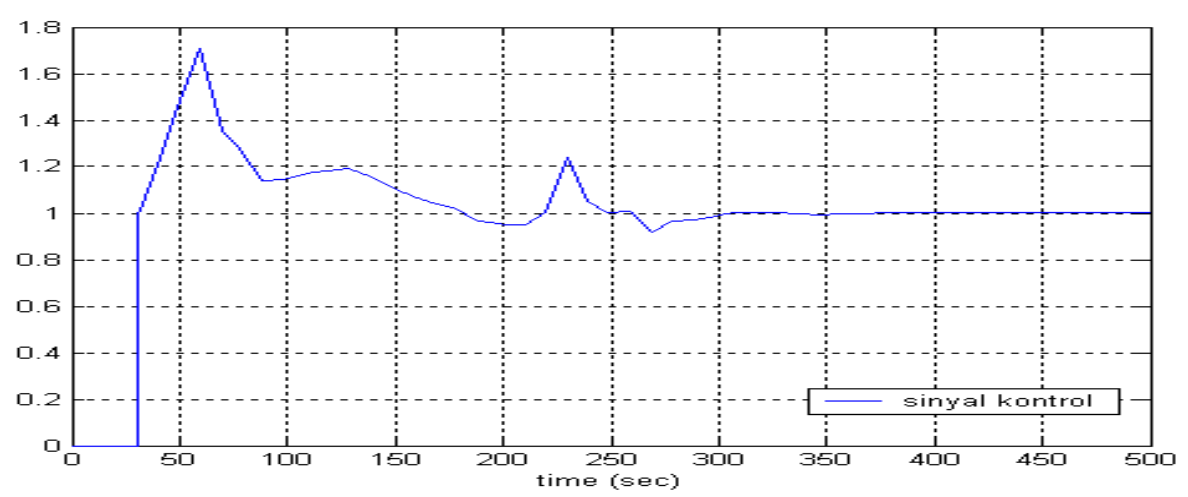

Gambar 21 Sinyal kontrol u(t) orde satu PID dengan gangguan.

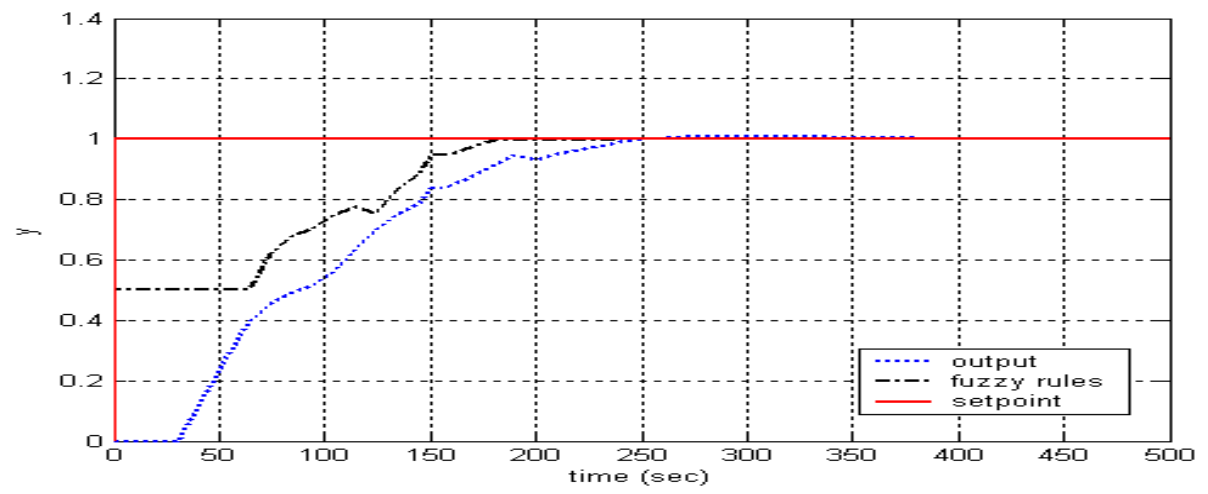

Gambar 22 Respon keluaran orde satu sistem kontrol hibrida sinyal rujukan berbasis logika fuzzy satu masukan dengan gangguan.

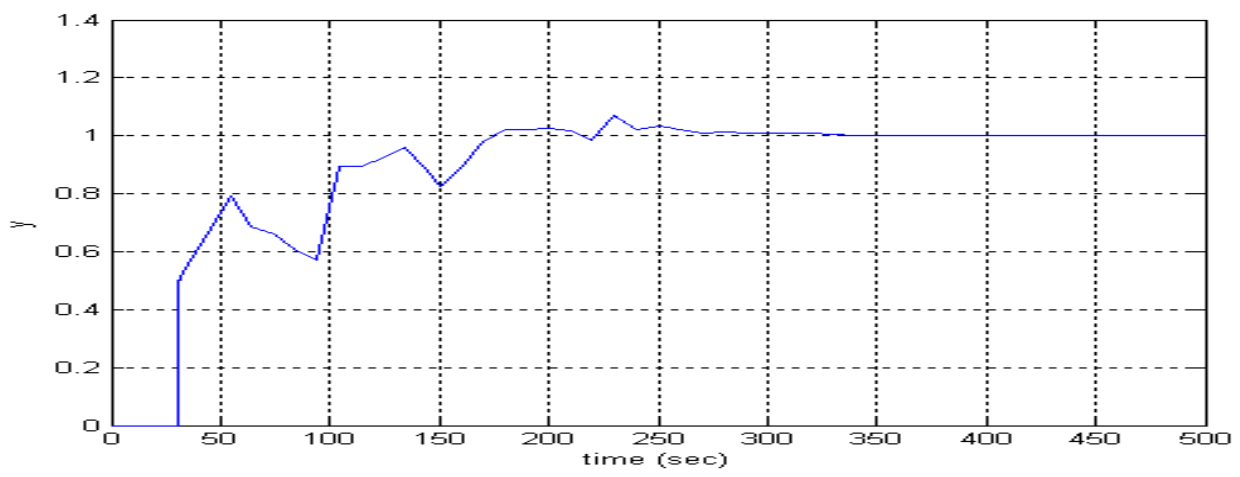

Gambar 23 Sinyal kontrol u(t) orde satu sistem kontrol hibrida sinyal rujukan berbasis logika fuzzy satu masukan dengan gangguan. 
Dari data Tabel 3 terlihat bahwa pengontrol hibrida sinyal rujukan mampu memperbaiki nilai lonjakan maksimum mencapai $0,88 \%$ tetapi waktu naik menjadi lebih besar $50 \%$, nilai waktu tunak diperbaiki lebih cepat sebesar 0,09\%, dan energi pengontrolan turun sebesar 14,95\% dibandingkan pengontrol PID. Gambar 20 memperlihatkan keluaran respon transien dari pengontrol PID dan Gambar 22 memperlihatkan keluaran respon transien dari pengontrol hibrida sinyal rujukan.

Tabel 3 Data Pengamatan Kinerja Respon Transien

\begin{tabular}{cccccccc}
\hline Pengontrol & $\begin{array}{c}\text { Sinyal } \\
\text { rujukan }\end{array}$ & $\mathbf{T r}(\mathbf{s})$ & $\mathbf{T d}(\mathbf{s})$ & $\mathbf{T p}(\mathbf{s})$ & $\mathbf{T s}(\mathbf{s})$ & $\int u^{2} d t$ & $\mathbf{M p ( \% )}$ \\
\hline PID & 1 & 87,4 & 61,2 & 152,38 & 272,38 & 1,07 & 18,5 \\
Sistem Kontrol & 1 & 247,05 & 72,9 & 257,9 & 248,06 & 0,910 & 0,88 \\
Hibrida & & & & & & \\
\hline
\end{tabular}

\subsection{Simulasi Sistem Kontrol Hibrida Sinyal Rujukan Berbasis Logika Fuzzy pada Sistem Orde Dua dengan Dead Time 30 Detik}

Sistem plant orde dua dituliskan dalam fungsi alih sebagai berikut :

$$
G(s)=\frac{5 e^{-30 s}}{s^{2}+9 s+20}
$$

Parameter PID dicari dengan menggunakan metoda coba-coba, sehingga di dapat nilai parameter-parameter $K_{p}=0,05, T_{i}=0,6$ detik dan $T_{d}=15$ detik.

Gambar 24 memperlihatkan keluaran respon transien PID yang stabil berosilasi, Gambar 25 memperlihatkan sinyal kontrol yang digunakan. Gambar 26 memperlihatkan respon transien sistem kontrol PID dengan pengontrol hibrida sinyal rujukan berbasis logika fuzzy dan Gambar 27 memperlihatkan sinyal kontrol yang digunakan.

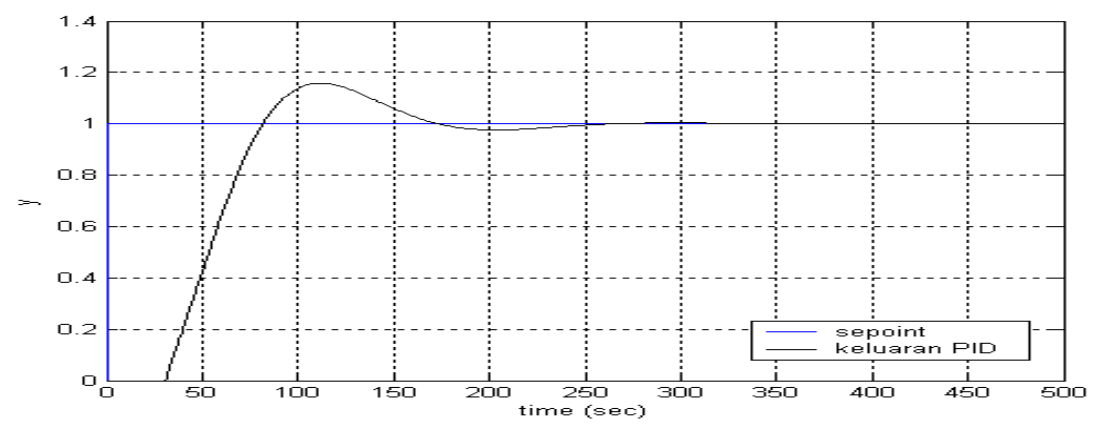

Gambar 24 Respon keluaran orde dua dengan pengontrol PID. 


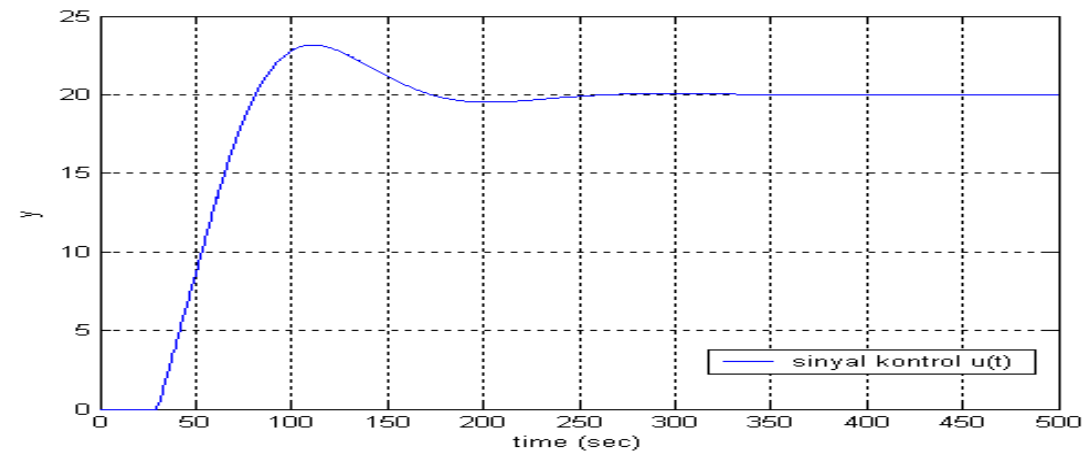

Gambar 25 Sinyal kontrol u(t) orde dua dengan pengontrol PID.

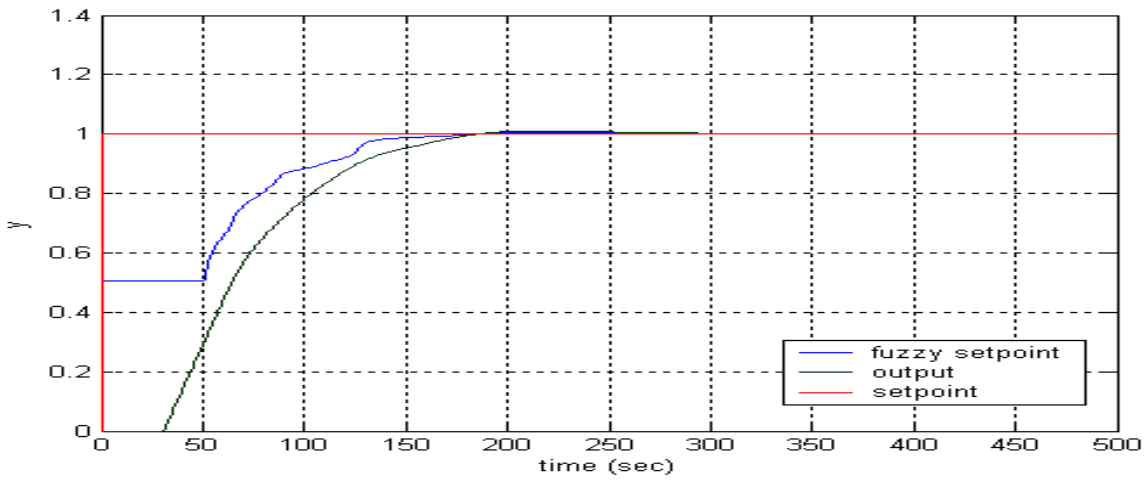

Gambar 26 Respon keluaran orde dua sistem kontrol hibrida sinyal rujukan berbasis logika fuzzy satu masukan.

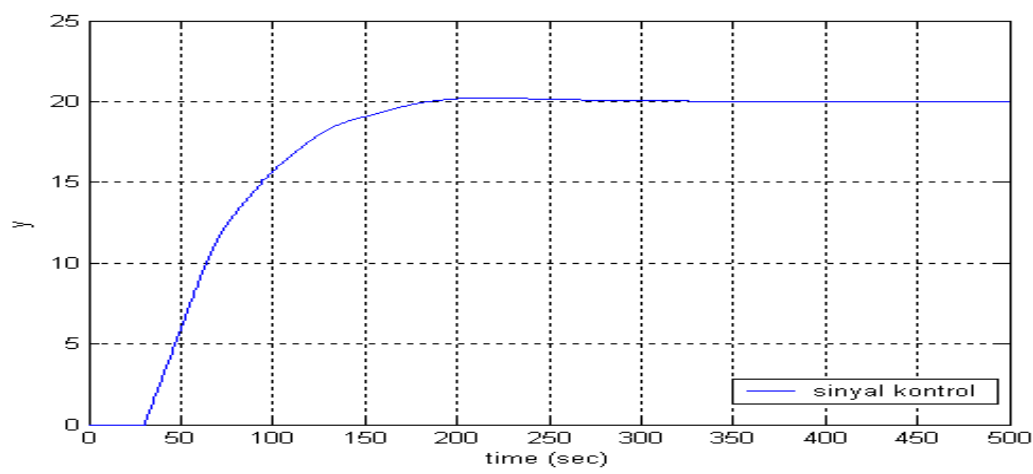

Gambar 27 Sinyal kontrol u(t) orde dua sistem kontrol hibrida sinyal rujukan berbasis logika fuzzy satu masukan.

Tabel 4 memperlihatkan kinerja respon keluaran pengontrol hibrida sinyal rujukan berbasis logika fuzzy yang dihasilkan pada sistem orde dua lebih baik 
dibandingkan respon keluaran pada sistem orde satu. Respon keluaran PID sistem orde dua dengan harga $M_{p}$ sebesar $0 \%$, nilai $T_{s}$ diperbaik lebih cepat 27,55\%, tetapi terjadi perlambatan $T_{r}$ sebesar $50 \%$, dan energi pengontrolan turun sebesar $0,03 \%$ dibandingkan pengontrol PID .

Tabel 4 Data Pengamatan Kinerja Respon Transien.

\begin{tabular}{cccccccc}
\hline Pengontrol & $\begin{array}{c}\text { Sinyal } \\
\text { rujukan }\end{array}$ & $\mathbf{T r}(\mathbf{s})$ & $\mathbf{T d}(\mathbf{s})$ & $\mathbf{T p}(\mathbf{s})$ & $\mathbf{T s}(\mathbf{s})$ & $\int u^{2} d t$ & $\mathbf{M p ( \% )}$ \\
\hline PID & 1 & 60,96 & 47,58 & 97.51 & 246.46 & 21.76 & 11.37 \\
$\begin{array}{c}\text { Sistem } \\
\begin{array}{l}\text { Kontrol } \\
\text { Hibrida }\end{array}\end{array}$ & 1 & 126,48 & 64.38 & 218.31 & 178.56 & 20.89 & 0 \\
\hline
\end{tabular}

\section{$5 \quad$ Kesimpulan}

Pada makalah ini telah dikembangkan metoda kontrol dengan mengontrol sinyal rujukan (set-point) berbasis logika fuzzy, sistem ini disebut sistem kontrol hibrida fuzzy sinyal rujukan. Pengontrol ini bekerja selama respon transien dengan memberikan sinyal rujukan semu untuk memperbaiki kinerja respon transien sistem kontrol lup tertutup pada sistem kontrol umpan balik dengan pengontrol PID. Metoda kontrol sinyal rujukan yang diusulkan menggunakan sistem keputusan dengan berdasarkan aturan logika fuzzy untuk menentukan besarnya sinyal rujukan semu yang akan diterapkan. Hasil-hasil simulasi memperlihatkan bahwa respon keluaran sistem kontrol lup tertutup dengan pengontrol PID yang cenderung mempunyai lonjakan maksimum dapat diturunkan bahkan dapat dihilangkan dengan sistem kontrol fuzzy sinyal rujukan. Terlihat pula bahwa untuk sistem orde satu dan sistem orde diperlukan logika fuzzy yang berbeda agar didapatkan respon transien yang diinginkan.

Hasil ini memberikan kemungkinan untuk mengurangi waktu dan usaha dalam tuning parameter PID di industri berkaitan dengan usaha untuk memperkecil lonjakan maksimum yang sering memakan waktu yang lama. Meskipun sistem kontrol hibrida fuzzy sinyal rujukan yang dikembangkan menggunakan satu masukan, sistem ini dapat dikembangkan untuk aturan fuzzy dengan dua masukan (sinyal kesalahan $e(t)$ dan turunan sinyal kesalahan $\dot{e}(t)$ ) ataupun dengan jumlah masukan yang lebih tinggi untuk menghasilkan kinerja yang lebih baik. 


\section{Daftar Pustaka}

[1] Takatsu, H., Itoh, T. \& Araki, M., Future needs for the control theory in industries: Report and Topics of the Control Technology Survey in Japanese Industry, J. Process Control, 8(5-6), 363-374, 1998.

[2] Joelianto, E., Linear Hybrid Reference Control Systems, PhD Thesis, The Australian National University, Canberra-Australia, 2000.

[3] Astrom, K. \& Hagglund, T., PID Controllers: Theory, Design, and Tuning, 2ed, Instrument Society of America (ISA), USA, 1995.

[4] Joelianto, E. \& Williamson, D., Discrete Event Reference Control, Proc. $36^{\text {th }}$ IEEE Conf. Decision Contr., San Diego-California, pp. 692-697, 1997.

[5] Joelianto, E. \& Williamson, D., Optimal Full State Hybrid Reference Control, in Mathematical Theory of Network and Systems, A. Beghi, L. Finesso and G. Picci (eds.), Padova-Italy, Il Poligrafo, pp. 941-944, 1998.

[6] Joelianto, E. \& Williamson, D., Observer based Hybrid Reference Control, Proc. $37^{\text {th }}$ IEEE Conf. Decision Contr., Tampa-Florida, pp.42964301, 1998.

[7] Zadeh, L.A., Outline of a new approach to the analysis of complex systems and decision processes, IEEE Trans. On Systems, Man and Cybern., SMC, 3(1), 1973.

[8] Takagi, T. \& Sugeno, M., Fuzzy identification of systems and its application to modeling and control, IEEE Trans. On Systems, Man and Cybern., SMC, 15(1), 1985.

[9] Wang, L.X., Adaptive Fuzzy Systems and Control: Design and Stability Analysis, Prentice Hall International, Englewood Cliffs, New Jersey, 1994.

[10] Zhao, Z.Y., Tomizuka, M. \& Isaka, S., Fuzzy Gain Scheduling of PID Controller, IEEE Trans. on Systems, Man and Cybern, SMC, 23(5), 1993.

[11] Hu, B., Mann, G.K.I. \& Cosine, R.G., New Methodology for Analytical and Optimal Design of Fuzzy PID Controllers, IEEE Trans. on Fuzzy Systems, 7(5), 1995.

[12] Stephanopoulus, G., Chemical Process Control, Prentice Hall Inc., Singapore, 1984.

[13] Coughanowr, D.R., Process Systems Analysis and Control, 2 Ed., McGraw-Hill International Edition, Singapore, 1991.

[14] Smith, C.A. \& Corripio, A.B., Principles an Practice of Automatic Process Control, John Wiley and Sons, Canada, 1985. 